\title{
Tri novejša dela hrvaškega narečjeslovja
}

\author{
Elöd Dudás
}

Đuro Blažeka, Međimurski dijalekt: hrvatski kajkavski govori Međimurja, Varaždin: Matica hrvatska, 2008 (Knjižnica Matice hrvatske 31), XII + 272 str.

Stjepan Belović - Đuro Blažeka, Rječnik govora Svetog Đurđa: rječnik ludbreške Podravine, Zagreb: Učiteljski fakultet, 2009 (Posebna izdanja 2), 599 str.

Đuro Blažeka - István Nyomárkay - Erika Rácz, Mura menti horvát tájszótár = Rječnik pomurskih Hrvata, Budapest: Tinta Könyvkiadó, 2009 (Segédkönyvek a nyelvészet tanulmányozásához 95), 396 str.

Prispevek predstavlja monografijo medžimurskega narečja in dva novejša narečna slovarja kajkavskih govorov s posebnim poudarkom na zgradbi slovarskih enot. Izpostavljen je pomen slovarjev za slovensko narečjeslovje, saj imajo nekateri vzhodnoslovenski govori skupne lastnosti s kajkavskimi govori. Predstavljene so konkretne vzporednice v zrcalu primerov med slovenskim središkim govorom in pomursko-medžimurskim narečjem ter govorom Svetega Đurđa.

Ključne besede: hrvaščina, slovenščina, medžimursko narečje, narečna slovnica, narečno slovaropisje, jezikovni stik

\section{Three new works in Croatian dialect studies}

This article presents a monograph on the Međimurje dialect and two recent dialect dictionaries of Kajkavian subdialects with a special emphasis on the structure of the lexicographic units. Emphasis is placed on the significance of the dictionaries for Slovenian dialectology because certain eastern Slovenian subdialects share characteristics with Kajkavian subdialects. Specific parallels are presented through examples as reflected in the Slovenian subdialect of Središče, the Mura Valley-Međimurje dialect, and the Sveti Đurđ subdialect.

Key words: Croatian, Slovenian, Međimurje dialect, dialect grammar, dialect lexicography, language contact

Hrvaški jezikovni prostor delimo po odrazu jata tradicionalno na tri narečne skupine: na kajkavsko (odraz jata je $e$ ), čakavsko (odraz jata je $i$ ) in štokavsko narečno skupino, kjer na mestu jata stoji $e$ (srbska knjižna različica) ali ijelje (hrvaška knjižna različica). Seveda lahko tudi te narečne skupine naprej delimo na manjše enote. Kajkavsko narečno skupino, katere narečja so jezikovno najbližja slovenščini, Mijo Lončarić (2009) po naglasnem sistemu in vokalizmu deli na 15 narečij. Eno izmed njih je medžimursko narečje, ki se je v zadnjih dveh letih obogatilo z monografijo 
(Blažeka 2008) in narečnim slovarjem pomurskih Hrvatov (Blažeka - Nyomárkay - Rácz 2009). Leta 2009 je izšel narečni slovar (Belović - Blažeka 2009), ki je prav tako velik prispevek h kajkavskemu narečjeslovju, obravnava pa govor kraja Sveti Đurđ, ki jezikovno pripada varaždinsko-ludbreškim narečjem, vendar ima več lastnosti medžimurskega narečja.

Monografija Đura Blažeka (2008), raziskovalca in dobrega poznavalca kajkavskih narečij, prinaša celovit pregled medžimurskega narečja. Avtor je snov razdelil na deset poglavij, ki bralcu ponujajo natančen znanstveni popis tega narečja. V uvodu lahko beremo, kako je avtor zbiral gradivo, kar je bilo posebej težko, ker so že šestdesetletni informatorji »premladi« za dialektološko raziskavo zaradi velikega vpliva hrvaškega knjižnega jezika (Blažeka 2008: 2). Najdemo tudi zgodovinski pregled dosedanjega raziskovanja medžimurskega narečja. Uvodu sledi poglavje s klasifikacijo medžimurskih govorov, v katerem so tri podnarečja razčlenjena na skupine govorov. Merili za delitev na podnarečja sta razmerje med odrazoma ě in polglasnika $\mathrm{v}$ nenaglašenem položaju in razmerje med odrazoma zlogotvornega $l$ in zadnjega nosnika $Q$ (Blažeka 2008: 12-13).

Posebna dragocenost te razdelitve je, da upošteva govor pomurskih Hrvatov, ki živijo na območju Madžarske in govorijo medžimursko narečje. Njihov govor je predstavljen na podlagi govora Serdahelja, največje pomurske hrvaške vasi na Madžarskem. Pred Blažekom ni bilo nobenega opisa tega narečja. V knjigi bralec spozna predvsem glasoslovje in oblikoslovje. Besedilo dopolnjujejo različne preglednice, ki omogočajo lažje razumevanje delitve medžimurskega narečja na podnarečja. Zelo dragoceno in koristno je poglavje, ki obravnava razmerja med medžimurskim narečjem in drugimi hrvaškimi kajkavskimi ter slovenskimi govori. Monografijo dopolnjujejo različni zemljevidi, npr. karta kajkavskega narečja in karta izbranih glasoslovnih in oblikoslovnih lastnosti. Posebej je treba poudariti, da so glasoslovni in oblikoslovni pojavi v monografiji ponazorjeni s številnimi primeri, ki potrjujejo zapisane trditve.

Poleg Blažekove monografije bi želel predstaviti še dva novejša dosežka hrvaškega narečjeslovja, oz. hrvaškega narečnega slovaropisja zadnjih dveh let, in sicer Slovar govora Svetega Đurđa (Belović - Blažeka 2009) in Slovar pomurskih Hrvatov (Blažeka - Nyomárkay -Rácz 2009). Slovar govora Svetega Đurđa zajema besedje vasi Sveti Đurđ. Kot je bilo že omenjeno, ta govor pripada varaždinsko-ludbreškemu narečju, vendar ima več značilnosti medžimurskega narečja. Zbiranje narečnega gradiva je delo Stjepana Belovića, ki je govorec tega narečja in se že več desetletij ukvarja z govorom svoje rodne vasi. Iz zbranega gradiva je izdelal slovar s pomočjo dialektologa Đura Blažeka, ki je poskrbel za strokovno plat pri ureditvi slovarja (fonetični zapisi, oblikovanje slovarskih enot). Drugi slovar, Slovar pomurskih Hrvatov, je rezultat mednarodnega sodelovanja hrvaškega dialektologa Đura Blažeka in madžarskega slavista, akademika Istvána Nyomárkayja ter Erike Rácz, ki je tik pred izidom slovarja doktorirala $\mathrm{z}$ disertacijo iz pomurske kajkavščine. Njen materni jezik je pomursko-medžimursko narečje. Ta slovar je posebno dragocen, ker spada med redka dela, ki se ukvarjajo s kajkavskim narečjem na Madžarskem, ki je več kot tisoč let prisotno na območju županije Zala. Pomursko-medžimursko narečje se govori ob reki Muri na hrvaško-madžarski državni meji. Ta 
slovar predstavlja govor vasi Mlinarci (Molnári), Murski Krstur (Murakeresztúr) in Serdahelj (Tótszerdahely). Namen slovarja je ohranitev in dokumentiranje še dostopnega narečnega besedja. Izhodišče za slovar je slovarsko gradivo Mlinarcev, dopolnjeno $\mathrm{z}$ besedami iz drugih dveh krajev.

Vemo, da narečja zaradi vpliva knjižnega jezika čedalje bolj izgubljajo svoje značilnosti. To še bolj velja za narečja manjšinskih jezikov, v dvojezičnem okolju, kjer ljudje govorijo še en jezik oz. državni jezik na isti ravni kot svojo materinščino (ali še boljše), saj ga uporabljajo v vsakodnevnih stikih. Narečje uporabljajo le v družinskem okolju ali na različnih manjšinskih prireditvah . Še bolj žalostno podobo pomurskih Hrvatov kažejo tile podatki. Po zadnjem popisu prebivalstva, leta 2001, v teh treh pomurskih vaseh živi 1346 ljudi, katerih materni jezik je hrvaščina oz. pomursko-medžimursko narečje. Dodali bi še lahko, da narečje govori le starejša generacija. To je razumljivo, saj se otroci v šolah učijo knjižno hrvaščino, ne pa narečja. Poleg teh dejstev moramo upoštevati še izseljevanje prebivalstva bodisi zaradi boljših možnosti za zaposlitev bodisi zaradi študija $\mathrm{v}$ večjih mestih, ki so daleč od domačega kraja. (Položaj porabskih Slovencev je zelo podoben položaju pomurskih Hrvatov.) Tukaj navedena dejstva bi lahko osvetlile sociolingvistične raziskave, s katerimi bi lahko dobili podrobnejše in natančnejše podatke o procesih, ki potekajo v ozadju in vplivajo na jezik in rabo jezika pripadnikov manjšin. Slovarsko gradivo so zbirale učiteljice pomurskih osnovnih šol; vodila jih je Erika Rácz. Fonetične zapise je naredil Đuro Blažeka. Zbrano gradivo je uredil István Nyomárkay.

Vsak od slovarjev vsebuje približno 10.000 slovarskih enot. Zgradba slovarskih enot v slovarjih je podobna. Sestavljene so iz štirih delov: iztočnice, slovničnega podatka, pomenske razlage in ponazarjalnega gradiva. Iztočnice so poknjižene (»arhileksemi«), torej so zapisane po pravilih hrvaškega knjižnega jezika in neonaglašene. Izjema je zapis zvenečih soglasnikov v izglasju. Kadar gre pri iztočnici za nestvarno (»arhileksemsko«) homonimijo, je s številko označena le poknjižena iztočnica, saj se kanonizirani narečni obliki razlikujeta, npr. v geslih $\mathrm{POD}^{1}$ kot onaglašeni samostalnik in $\mathrm{POD}^{2}$ kot neonaglašeni predlog. Pri stvarni homonimiji pa sta s številko označeni tako poknjižena iztočnica kot kanonizirana oblika, saj se tudi zadnji dve ne razlikujeta (Blažeka - Nyomárkay - Rácz 2009: 12, 17), npr. v geslih »CAPA ${ }^{1}\left[\mathbf{c}^{\prime}\right.$ apa $^{1}$ c'ape $^{\prime} \boldsymbol{f}$ šapa $[\ldots] \ll$ in $\mathrm{CAPA}^{2}\left[\mathbf{c}^{\prime}\right.$ apa $^{2}$ c'ape $]$ f morski pas $[\ldots] \ll$ (Blažeka - Nyomárkay - Rácz 2009: 44). Vsaka iztočnica ima tudi fonetični zapis v oglatem oklepaju, npr. »PES [p'ẹs p'ẹsa] $\boldsymbol{m}$ pas (LAT. Canis lupus familiaris L.) [...]« (Belović - Blažeka 2009: 308) in »PES [p'ẹs p'ẹsa] m pas $\mid$ kutya $\mid$ Hund [...]« (Blažeka - Nyomárkay - Rácz 2009: 207).

Pregibne besedne vrste so navedene v osnovnih slovarskih oblikah. V Slovarju govora Svetega Đurđa je dodana knjižna hrvaška ustreznica ali pomenska razlaga, npr. »NALEV [...] $\boldsymbol{m}$ povećanje obujma vimena prije teljenja. [...] (Be- $^{-}$ lović - Blažeka 2009: 252). V Slovarju pomurskih Hrvatov so poleg knjižnih hrvaških ustreznic ali pomenskih razlag dodane še madžarske in nemške ustreznice, npr. »NAMLATITI [...] pf. 1. istući, isprebijati | megver \|| prügeln [...] 2. završiti mlaćenje žita | befejezi a cséplést, sokat csépel || das Dreschen beenden [...]« (Blažeka - Nyomárkay - Rácz 2009: 176). V obeh slovarjih sledi posa- 
meznim razlagam ponazarjalni primer iz vsakdanjega govora, ki ga uvaja znak - V slovarjih je predstavljeno tudi frazeološko gradivo. Uvaja ga znak $\square$ in ga lahko najdemo na koncu slovarske enote, redkim frazemom pa so pripisani (ali vsaj nakazani) tudi pomeni, npr. »ITI [...] ם 'Idị v r'it! (lakša psovka | enyhébb szitok || gelinder Fluch)« (Blažeka - Nyomárkay - Rácz 2009: 108); »ITI [...] ם 'iț š 'irụm (početi se odljepljivati; razilaziti se)« (Belović - Blažeka 2009: 162). Pisava iztočnic s samo velikimi črkami lahko povzroča težave pri prepoznavanju lastnih imen. Mogoče bi bilo boljše, če bi bile iztočnice pisane z malimi črkami, kar bi olajšalo razumevanje bralcu, ki teh lastnih imen ne pozna. Mislim na manj znana lastna imena, ki jih lahko najdemo v obeh slovarjih, npr. »BARA [B'ọra B'ọre] foblik ženskog imena Barbara. « (Belović - Blažeka 2009: 55); »KANIŽA [Kan'iža Kan'že] $\boldsymbol{f}$ grad u jugozapadnoj Mađarskoj | Kanizsa \| Kanizsa [...] « (Blažeka - Nyomárkay - Rácz 2009: 118). Namen vseh narečnih slovarjev je tudi ohranitev poimenovanj iger, manj znanih poljedelskih izrazov itn. V tem lahko narečni slovarji pomagajo etnologom in vsem bralcem, ki jih zanimajo te besede. V obeh slovarjih lahko naletimo na mnoge take besede, npr. »ČEBRICA

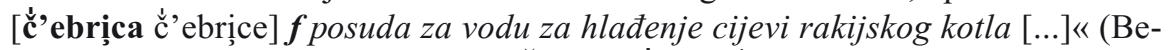
lović - Blažeka 2009: 88); »BATAČ [b'ọtac̆ b'ọtac̆̉a] $\boldsymbol{m}$ rubac koji se stavlja na rame - dio narodne nošnje | virágos népviseleti vállkendö || blumengeschmücktes Schultertuch [...]« (Blažeka - Nyomárkay - Rácz 2009: 28).

Slovarsko gradivo obeh slovarjev je tudi idealna osnova za raziskovanje medjezikovnih stikov, saj vsebuje precej germanizmov (cimerman 'tesar', dunst 'para', fertik 'gotov', fraj 'svoboden') in hungarizmov (berek 'močvirno ozemlje', đund 'biser', fela 'vrsta', jezero 'tisoč'). Seveda je več hungarizmov v Slovarju pomurskih Hrvatov, saj ti živijo v dvojezičnem okolju, kjer vsak dan prihajajo v stik z madžarskim jezikom. (Madžarsko-hrvaške jezikovne stike natančno predstavlja László Hadrovics (1985).) V Slovarju govora Svetega Đurđa gre za staro plast prevzetih madžarskih besed. Vzroki za izposojo segajo v zgodovino, saj so se kajkavščina, vzhodna slovenščina, nemščina in madžarščina skozi stoletja prepletale in vplivale druga na drugo. Večstoletno sobivanje je lepo razvidno tudi v teh jezikih. Gradivo bi lahko uporabili za arealne raziskave skupnih pojavov v sosednjih jezikih. $V$ pomoč bi bilo tudi pri raziskavah skupnih vplivov latinščine in nemščine, ki sta bili v tem prostoru zelo pomembni, na hrvaščino, madžarščino in slovenščino.

Slovarja sta zelo pomembna prav s slovenskega stališča. Razpravljanje o izvoru in sorodnosti vzhodnih slovenskih in kajkavskih govorov sega vse do 19. stoletja (Lundberg 2003: 55). »Nekateri prleški in haloški govori so morda kajkavskega izvora, saj izkazujejo kajkavski sovpad prvotnih $*_{e}$ in $*_{b} / b$, « pravi Greenberg (2002: 27). V nadaljevanju bi rad predstavil nekatere vzporedne pojave med medžimurščino in govorom Svetega Đurđa ter slovenskim središkim govorom (središke primere navajam po Greenberg 1999). Govor kraja Središče ob Dravi pripada prleškim narečjem in ima skupne lastnosti in podobnosti z nekaterimi kajkavskimi govori, ki izhajajo iz praslovanske dediščine. 
(1) na mestu $b$ je $e$, npr. medžimursko den [d'ien], megla [m'ęgla], pes [p'ês]; Sveti Đurđ den [d'eㅡ], megla [m’ẹgla], pes [p’ẹs]; središko den [dện], megla [mägla], pes [päs];

(2) odraz jata je $e$, npr. medžimursko breg [br'iek], greh [gr'êh], mesto [m'ẹstụ]; Sveti Đurđ breg [br'iek], greh [gr'ieh], mesto [m’ẹstụ]; središko breg [brệg], greh [grệh], mesto [mę̂sto];

(3) izguba razlike $l$ in $l$ ', ki je govor Svetega Đurđa ne pozna, npr. medžimursko kluč [kl'uč̀], kral [kr'ọl], ludi [l'udị], zemla [z'ȩmla]; središko kluč [klûč], kral [krậl], ludi [lûdi], zemla [zêmla];

(4) prehod $v \rightarrow f$ pred (a) nezvenečimi priporniki in (b) na koncu besed: medžimursko (a) fpelati [fp'ẹlati], fpičiti (se) [fp'ičițiț (se)], ftrnuti [ft'rnụtị]; (b) cev [c'ief], črv [č̀'rf]; Sveti Đurđ (a) fpičiti (se) [fp'ičititi (se)], ftrčiti se [ft'rč̀itị se]; (b) cev [c'ief], črv [č̀'rf]; središko (a) vsipati [fsïpati], vteknoti [ftäknoti], vtič [ftïč]; (b) cev [cệf], črv [čr̂rf];

(5) protetični v-: medž. vuho [v'uhụ], vuš [v'uš]; Sveti Đurđ vuho [v'uhụ], vuš [v'uš]; sred. vuho [vûho], vuš [vûš].

Po mojem mnenju imata hrvaška in slovenska dialektologija odprta skupna vprašanja o podobnosti med vzhodnimi slovenskimi narečji in kajkavskimi govori. To bi zahtevalo skupne programe za natančnejše raziskave narečnega gradiva in za primerjavo narečij, kar vse bi pomagalo pri reševanju zapletenih vprašanj mednarečnih razmerij.

Monografija in oba slovarja so dobri primeri natančnega raziskovanja in obdelovanja narečnega gradiva. Ponujajo podatke na znanstveni ravni in so lahko uporabni tudi na drugih znanstvenih področjih, npr. v etnologiji. To so zelo dragocena dela, saj imamo po njihovi zaslugi več podatkov, ki bogatijo hrvaško dialektologijo in naše védenje o medžimurskem narečju in o govoru Svetega Đurđa.

\section{Literatura}

Belović - Blažeka 2009 = Stjepan Belović - Đuro Blažeka, Rječnik govora Svetog Đurđa: rječnik ludbreške Podravine, Zagreb: Učiteljski fakultet, 2009 (Posebna izdanja 2).

Blažeka 2008 = Đuro Blažeka, Međimurski dijalekt: hrvatski kajkavski govori Međimurja, Varaždin: Matica hrvatska (Knjižnica Matice hrvatske 31), 2008.

Blažeka - Nyomárkay - Rácz 2009 = Đuro Blažeka - István Nyomárkay - Erika Rácz, Mura menti horvát tájszótár = Rječnik pomurskih Hrvata, Budapest: Tinta Könyvkiadó, 2009 (Segédkönyvek a nyelvészet tanulmányozásához 95).

Greenberg 1999 = Marc L. Greenberg, Slovarček središkega govora, Slovenski jezik - Slovene Linguistic Studies 2 (1999), 128-175.

Greenberg 2002 = Marc L. Greenberg, Zgodovinsko glasoslovje slovenskega jezika, Maribor: Aristej, 2002. 
- Hadrovics 1985 = László Hadrovics, Ungarische Elemente im Serbokroatischen, [त. Budapest: Akadémiai Kiadó, 1985.

N Lončarić 2009 = Mijo Lončarić, O klasifikaciji slovenskoga i hrvatskoga jezika s posebnim osvrtom na kajkavsko narječje, v: Slovenska narečja med sistemom in rabo = Obdobja 26, ur. Vera Smole, Ljubljana: Filozofska fakulteta, 2009, $277-289$.

Lundberg $2003=$ Grant H. Lundberg, A Preliminary Report on Dialectological Fieldwork in Northwestern Croatia: Brezova Gora and the Croatian-Slovene Dialect Continuum, Slovenski jezik - Slovene Linguistic Studies 4 (2003), 55-64. 